\title{
Sex-specific expression of a novel gene Tmem184a during mouse testis differentiation
}

\author{
Terje Svingen, Annemiek Beverdam, Pascal Bernard ${ }^{1}$, Peter McClive ${ }^{2}$, Vincent R Harley ${ }^{1}$, Andrew \\ $\mathrm{H}$ Sinclair ${ }^{2}$ and Peter Koopman \\ Institute for Molecular Bioscience, The University of Queensland, Brisbane, Queensland 4072, Australia, ${ }^{1}$ Human \\ Molecular Genetics Laboratory, Prince Henry's Institute of Medical Research, Monash Medical Centre, Clayton, \\ Victoria 3168, Australia ${ }^{2}$ Murdoch Children's Research Institute and Department of Paediatrics, University of \\ Melbourne, Royal Children's Hospital, Parkville, Victoria 3052, Australia
}

Correspondence should be addressed to P Koopman; Email: p.koopman@imb.uq.edu.au

\begin{abstract}
During mouse embryogenesis, the fate of the bipotential gonads is sealed around 10.5 days post coitum (dpc) when the Y-linked gene Sry specifies the differentiation of testes in males, whereas in females, absence of Sry results in ovary formation. Apart from the pivotal action of Sry, many other genes are known to be involved in sex determination and subsequent differentiation. Much is still unknown regarding the regulatory hierarchy governing these events and many more sex differentiation genes are yet to be discovered. In this study, we investigated the expression of Tmem184a, a novel gene encoding a protein of unknown function, but with predicted kinase activity, during mouse embryogenesis. We show that Tmem184a is expressed at high levels in the developing testis from $11.5 \mathrm{dpc}$, a time of active proliferation and differentiation. Tmem184a expression is further shown to be expressed exclusively within the Sertoli cells of the developing testis cords, suggesting that it may mediate sex-specific signaling events during Sertoli cell differentiation.

Reproduction (2007) 133 983-989
\end{abstract}

\section{Introduction}

In most mammals, sex is determined by the function of Sry, a gene that resides on the $\mathrm{Y}$ chromosome. In mice, Sry expression is induced within $\mathrm{XY}$ genital ridges around 10.5 days post coitum (dpc; Koopman et al. 1990), after which the XY gonad enters a stage of active differentiation (reviewed by Brennan \& Capel 2004). The developing testis is most notably distinguishable from the more latent ovary during this period by the formation of testis cords. This process involves dramatic tissue reorganization and proliferation, along with recruitment of several cell lineages that migrate into the gonad from the adjacent mesonephros and the coelomic epithelium (Martineau et al. 1997, Karl \& Capel 1998, Val et al. 2006). By $12.5 \mathrm{dpc}$, roughly $48 \mathrm{~h}$ after the initiation of Sry expression, the testis becomes compartmentalized into cords, which consist of germ cells and supporting Sertoli cells encapsulated by a thin layer of peritubular myoid cells, and the interstitium composed of endothelial, Leydig, and connective tissue cells.

Of the various cell lineages making up the testis, only the Sertoli cells express Sry (Albrecht \& Eicher 2001, Sekido et al. 2004). Sertoli cells are known to influence differentiation of other testicular cell types and thus play a critical inductive role in testis development (Burgoyne et al. 1988; reviewed by Wilhelm \& Koopman 2006). One of the first critical steps in the testis-determining pathway is activation of Sox9 (Vidal et al. 2001, Chaboissier et al. 2004, Barrionuevo et al. 2006). However, the genetic pathways downstream of Sry that regulate sex determination and Sertoli cell differentiation remain largely unclear.

To further understand the regulatory pathways governing these processes, it is necessary to identify novel genes involved in sex-specific differentiation of the gonad. Many researchers have used expressionscreening strategies, including microarray studies, in an effort to identify a plethora of genes showing sexually dimorphic expression in gonads. We decided to further explore the spatiotemporal expression pattern of a novel gene with accession no. BC019731, which was shown in two such studies to be up-regulated at $11.5 \mathrm{dpc} X Y$ gonads when compared with XX gonads (Nef et al. 2005, Beverdam \& Koopman 2006).

Tmem184a spans a $9.3 \mathrm{~kb}$ region on chromosome 5 and was initially identified in a mouse cDNA library 
screen (Strausberg et al. 2002), with subsequent updated annotations (Nef et al. 2005). TMEM184a has a predicted kinase activity; however, its amino acid sequence does not align to any known domains and hence the function of this protein is unknown. Mouse Tmem184a has putative orthologs in a number of mammalian species, including human (Homo sapiens; Q6ZMB5), chimpanzee (Pan troglodytes; LOC735493), dog (Canis familiaris; LOC489896), and rat (Rattus norvegicus; RGD1306702). Homology between these putative orthologs is more than $80 \%$, and hence sufficiently high to be confident that the genes are orthologs and potentially have conserved function across species. In mouse, only one paralogous gene (4732495E13Rik/Tmem184b) has been identified (sharing putative domains of around $80 \%$ homology), with the two gene products making up a predicted MAP kinase-activating protein family of two members.

The involvement of kinase regulatory pathways during testis differentiation is poorly understood and has the potential to shed light on several unexplained aspects of these morphological events. As a first step toward elucidating the role of Tmem184a during mouse developments, we studied in detail its expression pattern and found it to be specifically up-regulated within the testis shortly after gonadal sex determination, with continued testis-specific expression into adulthood. The restricted expression of this gene in Sertoli cells suggests a role for the encoded protein in the development and/or continued function of that cell type.

\section{Materials and Methods}

\section{Animals}

Mouse embryos were collected from timed matings of the CD1 outbred strain and the $\mathrm{W}^{\mathrm{e}}$ mutant inbred strain, with noon of the day on which the mating plug was observed designated $0.5 \mathrm{dpc}$. Embryos at $11.5 \mathrm{dpc}$ or younger were sexed by RT-PCR using Zfy gene-specific primers Zfy F: 5'-CCTATTGCATGGACTGCAGCTTATG and Zfy R: 5'-GACTAGACATGTCTTAACATCTGTCC. Older embryos were sexed by morphological assessment of gonads.

\section{RNA isolation, CDNA synthesis, and SYBR green real- time RT-PCR}

Fetal gonads were collected by dissection, pooled according to sex and developmental stage (one litter per pool), and total RNA was isolated using the SV Total RNA Isolation System (Promega) as per manufacturer's instructions. cDNA was synthesized from $1 \mu \mathrm{g}$ total RNA by RT (Superscript III, Invitrogen) using random primers (Promega) according to manufacturer's instructions.
Relative cDNA levels were analyzed by quantitative real-time RT-PCR (qRT-PCR) using an ABIPrism-7000 Sequence Detector System.

For statistical significance, all qRT-PCR experiments were performed in triplicate and repeated thrice on separate biological samples, each representing one pooled litter (7-10 littermates/sex), and finally represented as mean \pm S.E.M. of the three individual experiments. Samples were analyzed in $25 \mu \mathrm{l}$ reactions containing SYBR Green PCR Master Mix (Applied Biosystems, Foster City, CA, USA), $3.75 \mu \mathrm{M}$ each forward and reverse primers, and $1 \mu \mathrm{l}$ cDNA, prepared as described using an ABIPrism-7000 Sequence Detector System. PCR was conducted over 40 cycles of $95{ }^{\circ} \mathrm{C}$ for $15 \mathrm{~s}$ and $60{ }^{\circ} \mathrm{C}$ for $1 \mathrm{~min}$ in a two-step thermal cycle, preceded by an initial 10 -min step at $95^{\circ} \mathrm{C}$ to activate the Amplitaq Gold DNA polymerase. The primers were designed using the Universal Probe library tool (http://www.roche-applied-science.com/sis/rtpcr/upl/ adc.jsp) as previously described (Beverdam \& Koopman 2006) and for this study, the primers used were rtTmem184a.F: 5'-CTGCATTGTGAAACCCGTTA and rtTmem184a.R: 5'-GGTAGCCGCTGTGGATGT; rtSox9.F: 5'-AGTACCCGCATCTGCACAAC and rtSox9.R: 5'-TACTTGTAATCGGGGTGGTCT; and rtOct4.F: 5'-TGCGGAGGGATGGCATACTG and rtOct4.R: 5'-GCACAGGGCTCAGAGGAGGTTC. To adjust for variation in input cDNA, samples were normalized against $18 S$ RNA using the $\Delta \mathrm{Ct}$ method. $18 \mathrm{~S}$ primers used were rt18S.F: $5^{\prime}-$ GATCCATTGGAGGGCAAGTCT and rt18S.R: 5'-CCAAGATCCAACTACGAGCTTTTT. Dissociation curve analyses were performed.

\section{Whole-mount and section in situ hybridization (WISH/SISH)}

Embryos and dissected gonads/mesonephroi were fixed in $4 \%$ paraformaldehyde (PFA) in PBS for several hours at $4{ }^{\circ} \mathrm{C}$. WISH with digoxygenin (DIG)-labeled RNA probes was carried out essentially as described by Hargrave et al. (2006). For SISH samples, whole embryos were processed and mounted in paraffin wax and stored at $4{ }^{\circ} \mathrm{C}$. SISH was performed on $7 \mu \mathrm{m}$ sagittal sections that were dewaxed, rehydrated, and incubated in $5 \mu \mathrm{M} / \mathrm{ml}$ proteinase $\mathrm{K}$ for $20 \mathrm{~min}$ at room temperature (RT), after which samples were washed in PBS. Sections were re-fixed with 4\% PFA for 10 min at RT, acetylated, and pre-hybridized with hybridization solution $(50 \%$ formamide, $5 \times$ SSC, $5 \times$ Denhardt's solution, $250 \mu \mathrm{g} / \mathrm{ml}$ yeast RNA, and $500 \mu \mathrm{g} / \mathrm{ml}$ herring sperm DNA) for $2 \mathrm{~h}$ at RT. Hybridization $(0.5 \mu \mathrm{g} / \mathrm{ml}$ probe in hybridization solution) was performed overnight at $60^{\circ} \mathrm{C}$. Slides were washed in $5 \times$ SSC for $5 \mathrm{~min}, 0.2 \times$ SSC for $1 \mathrm{~h}$ at $60{ }^{\circ} \mathrm{C}, 0.2 \times \mathrm{SSC}$ for $5 \mathrm{~min}$ at RT, and NT buffer $(150 \mathrm{mM} \mathrm{NaCl}, 50 \mathrm{mM}$ Tris- $\mathrm{HCl}(\mathrm{pH} 7.5))$ for $5 \mathrm{~min}$ at $\mathrm{RT}$, before blocking for $2 \mathrm{~h}$ with blocking solution $(10 \%$ heat-inactivated sheep serum in NT buffer) in a humidified chamber. Anti-DIG antibody (Roche) in 
blocking solution (1:2000) was added to the slides and incubated overnight at $4{ }^{\circ} \mathrm{C}$. Unbound antibodies were removed by washing thrice in NT buffer. Section were equilibrated in NTM buffer $(100 \mathrm{mM} \mathrm{NaCl}, 100 \mathrm{mM}$ Tris- $\mathrm{HCl}\left(\mathrm{pH}\right.$ 9.5), $50 \mathrm{mM} \mathrm{MgCl}_{2}$ ) and incubated in color solution (3.5 $\mu$ I BCIP (Roche), $3.5 \mu$ I NBT (Roche) per ml NTM buffer) until staining was detected.

A $273 \mathrm{bp} \mathrm{Tmem184a} \mathrm{fragment} \mathrm{was} \mathrm{cloned} \mathrm{from}$ position 419-692 (accession no. BC019731) into pGEM-T Easy vector (Promega). Primers used were Tmem184a.F: 5'-TTCCCCAGCCAGGTGTATTCAG and Tmem184a.R: 5'-TGCGTTTCTCTATGTTGCGACTC. The probes for Amh, Sox9, and Oct4 were made as previously described (Münsterberg \& Lovell-Badge 1991, Wright et al. 1995, Schepers et al. 2003).

\section{Results}

\section{Embryonic Tmem184a expression}

To study the expression pattern of Tmem184a during embryogenesis, we first conducted qRT-PCR and SISH analyses on $13.5 \mathrm{dpc}$ mouse embryos and tissues. qRTPCR assays revealed higher levels of Tmem184a transcripts in the testis when compared with ovary, brain, heart, liver, lung, limb, and kidney (Fig. 1A). Low levels of expression were detected within the ovaries, liver, and lung, but no expression was detected in the remaining tissues. SISH on whole embryos confirmed the qRT-PCR data, with a clear and specific hybridization signal restricted to the testis (Fig. 1B).
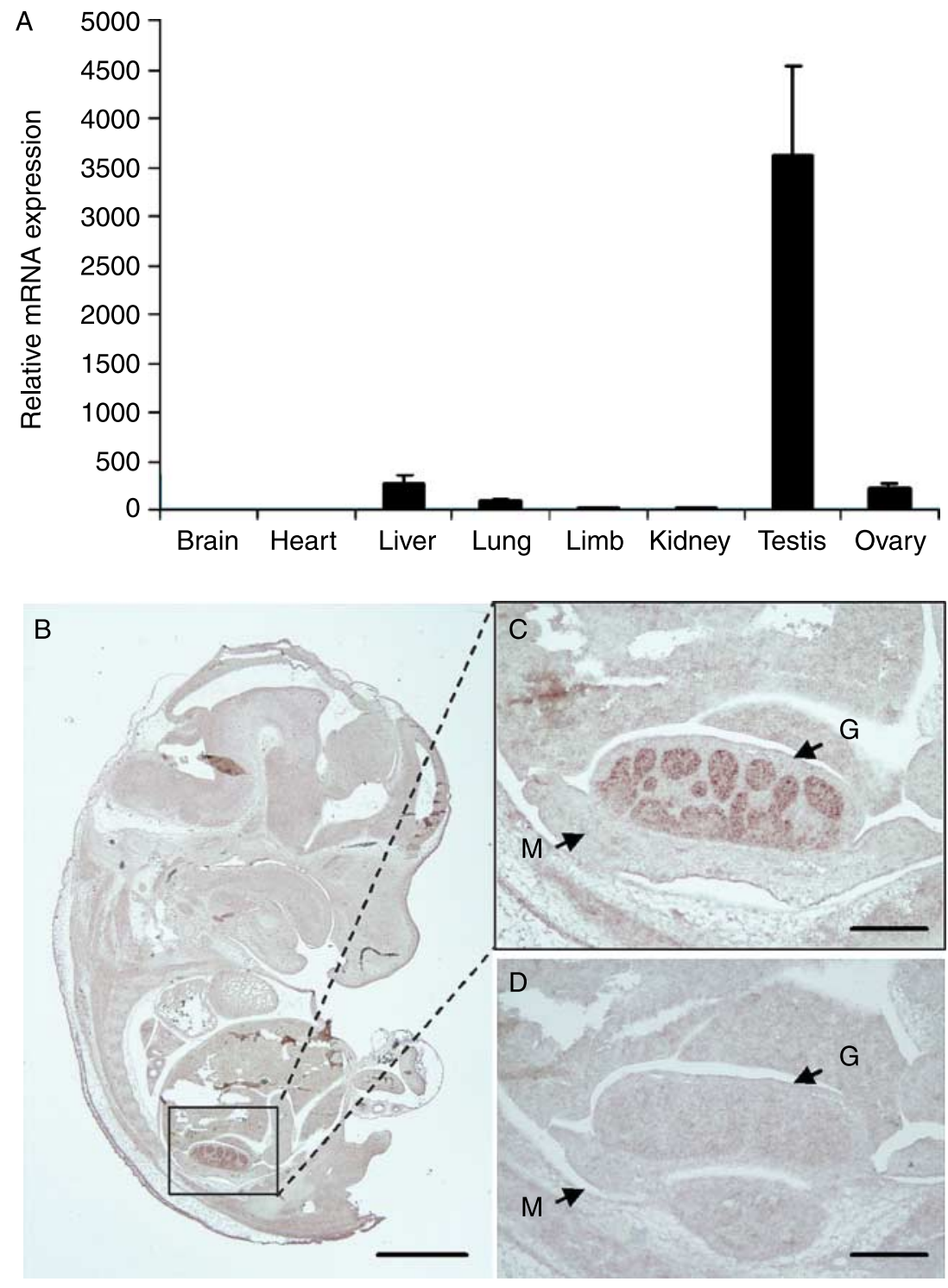

Figure 1 Testis-specific expression of Tmem184a in the mouse embryo. (A) qRT-PCR analysis of Tmem184a mRNA expression relative to $18 \mathrm{~S}$ RNA (mean \pm S.E.M. of three independent experiments, each performed in triplicate) in $13.5 \mathrm{dpc}$ mouse embryonic tissues. For each experiment, non-gonadal tissues were pooled from at least three littermate embryos, and testes and ovaries with attached mesonephroi were pooled from at least six littermates. Tmem184a shows high expression in testis and only weak expression in liver, lung, and ovary. No expression was detected in other tissues examined. (B) DIG-labeled sagittal SISH on 13.5 dpc male embryo. Strong Tmem184a expression is evident in the testis when compared with other tissues and (C) expression is restricted to the testis cords. (D) No staining was evident with a Tmem184a sense riboprobe. $G$, gonad; $M$, mesonephros. Scale bar $=1 \mathrm{~mm}$ (B); $200 \mu \mathrm{m}$ (C and D). 


\section{Temporal profile of Tmem184a expression in the developing gonads}

Next, we studied the temporal expression profile of Tmem184a at 10.5-16.5 dpc in the gonads of both sexes (Fig. 2A). Tmem184a mRNA was up-regulated in the testes from $11.5 \mathrm{dpc}$, with roughly fourfold higher levels of transcription detected relative to the levels of transcription in ovaries at this stage. Expression levels continue to increase in the testes until $16.5 \mathrm{dpc}$, whereas they remain low in the ovaries during the same period of time. WISH analyses confirmed this temporal expression pattern (Fig. 2B), with a weak signal detected in the testes at $11.5 \mathrm{dpc}$, becoming increasingly intense at 12.5 and $13.5 \mathrm{dpc}$. In the ovaries, only a weak staining was observed at these latter stages (Fig. 2B).

\section{Cell-specific Tmem184a expression within the fetal testis}

To identify the cell types that express Tmem184a, we performed SISH using specific probes for Tmem184a, the Sertoli cell marker Amh, and the germ cell marker Oct4 (Fig. 3). Sertoli cell nuclei are located peripherally in the developing testis cords, but their cytoplasms project toward the center of the cords, surrounding the germ cells. Their cytoplasms are therefore stellate, in contrast to the characteristic annular cytoplasms of the germ cells that are concentrated toward the lumen of the testis cords. A stellate hybridization pattern was observed with both the Tmem184a- and Amh-specific probes typical of Sertoli cell gene expression, and clearly differs from the pattern of Oct 4 probe hybridization (compare Fig. $3 \mathrm{~A}, \mathrm{D} /$

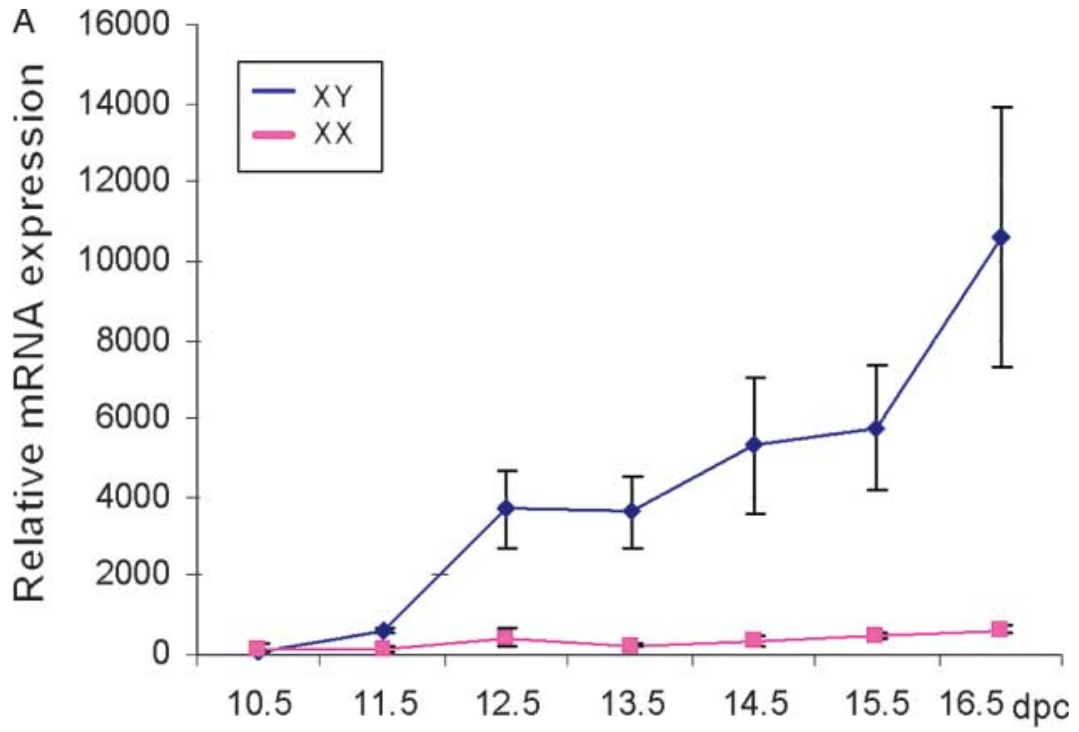

B

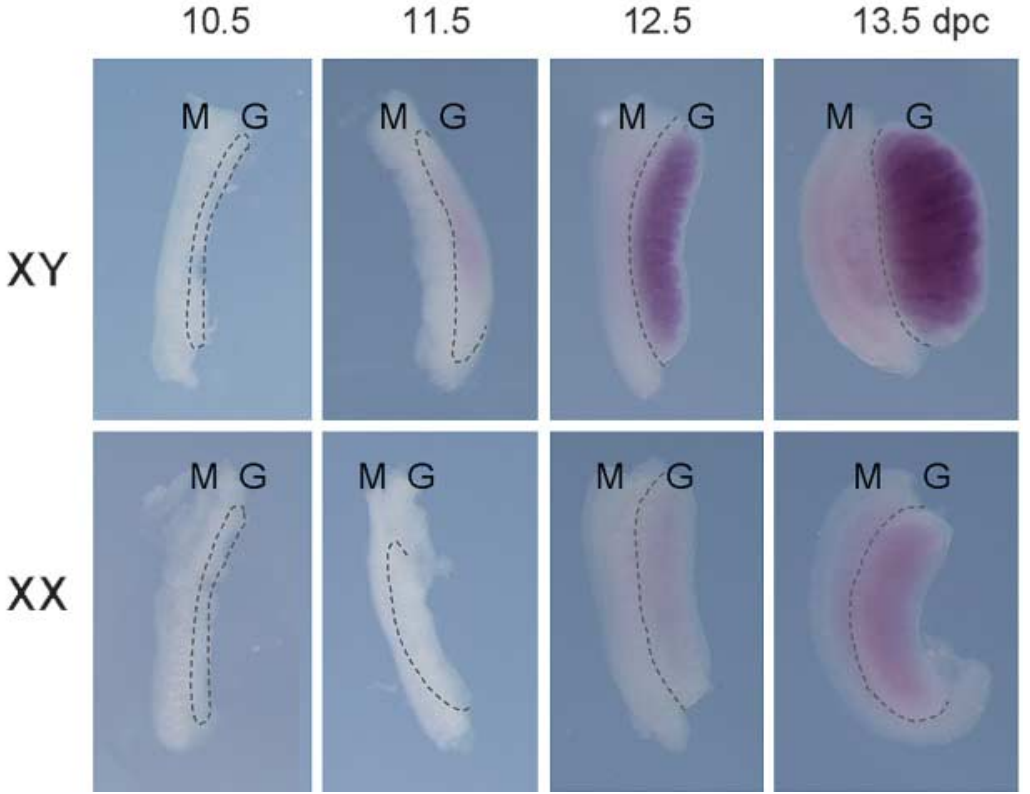

Figure 2 Temporal expression analysis of Tmem184a in the fetal gonads. (A) qRT-PCR analysis of Tmem184a mRNA expression relative to $18 S$ RNA (mean \pm S.E.M. of three independent experiments, each performed in triplicate) showing male-specific up-regulation in fetal gonads from $11.5 \mathrm{dpc}$. Individual experiments were performed on RNA obtained from pooled gonads from at least six littermates. Stage 10.5 and $11.5 \mathrm{dpc}$ gonads had mesonephroi attached, whereas later-stage gonadal samples had mesonephroi removed. (B) WISH analysis confirming male-specific up-regulation of Tmem184a in fetal gonads from $11.5 \mathrm{dpc}$. A weak signal was evident in ovaries from $12.5 \mathrm{dpc}$, but with a markedly stronger signal in the testis. Dotted lines mark the mesonephric-gonadal boundaries. $M$, mesonephros; G, gonad. 


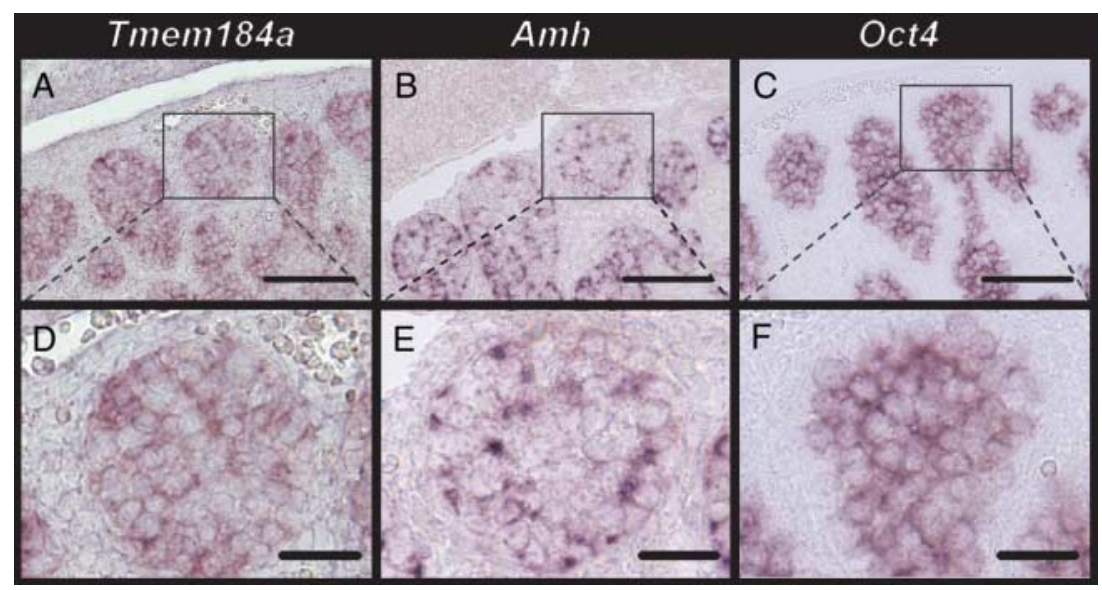

Figure 3 Cell-specific Tmem184a expression in the fetal male gonad. SISH staining of $13.5 \mathrm{dpc}$ male gonads using specific probes for Tmem184a (A and D), the Sertoli cell marker Amh (B and E), and the germ cell marker Oct4 (C and F).

Tmem184a is expressed in the testis cords and localizes to Sertoli cells. Tmem184a is not expressed in germ cells with staining different to that observed for the germ cell marker Oct4, as evident by the opposing staining between Tmem184a/Amh and Oct4 within the same testis cord (compare D/E with F). Boxed areas in $\mathrm{A}, \mathrm{B}$, and $\mathrm{C}$ indicate regions shown in $D, E$, and $F$ respectively. Scale bar $=100 \mu \mathrm{m}(\mathrm{A}-\mathrm{C}) ; 25 \mu \mathrm{m}(\mathrm{D}-\mathrm{F})$.

B, E and C, F). Tmem184a was not detected in any other cell types of the testis, including peritubular myoid cells, and therefore appear to be specific to Sertoli cells.

To further characterize the cell-specific expression of Tmem184a within the developing testis, qRT-PCR analyses were first performed on RNA collected from wild-type and $W^{e} / W^{e} \mathrm{XY}$ gonads, which are devoid of germ cells (Buehr et al. 1993; Fig. 4A). Similar to the expression of the Sertoli cell-specific gene Sox9, Tmem184a expression persists in the $W^{e} W^{e}$ gonads when compared with wild-type littermates. In contrast, expression of the germ cell marker Oct4 was lost in the $W^{e} W^{e}$ gonads as expected. The apparent increase in the expression levels of both Sox9 and Tmem184a in $W^{e} / W^{e} \mathrm{XY}$ gonads when compared with wild-type littermates is likely due to the increased overall proportion of somatic cells in the absence of germ cells in $W^{e} / W^{e}$ XY gonads. WISH experiments confirmed the persistent expression of Tmem184a in the testis cords of $W^{e} / W^{e} \mathrm{XY}$ gonads (Fig. 4B). These data clearly show that Tmem184a expression is not dependent on the presence of germ cells and is associated with somatic cells.

\section{Adult Tmem184a expression}

Finally, we performed qRT-PCR analyses on adult mouse tissues to establish whether Tmem184a remained up-regulated in the adult testis. As in fetal tissues, the expression levels of Tmem184a in adult testis were far higher than those in other tissues examined (Fig. 5A). SISH experiments further confirmed persistent Tmem184a expression in adult testis with Tmem184a expression pattern similar to that of the Sertoli cell marker Sox9 (Fig. 5B-E), with both gene transcripts detected in the periphery of the testis cords. Close examination of sections indicated a lack of Tmem184a expression in peritubular myoid cells, and the expression was Sertoli cell-specific.

\section{Discussion}

In the present study, we have analyzed the expression pattern of a novel gene, Tmem184a, during mouse
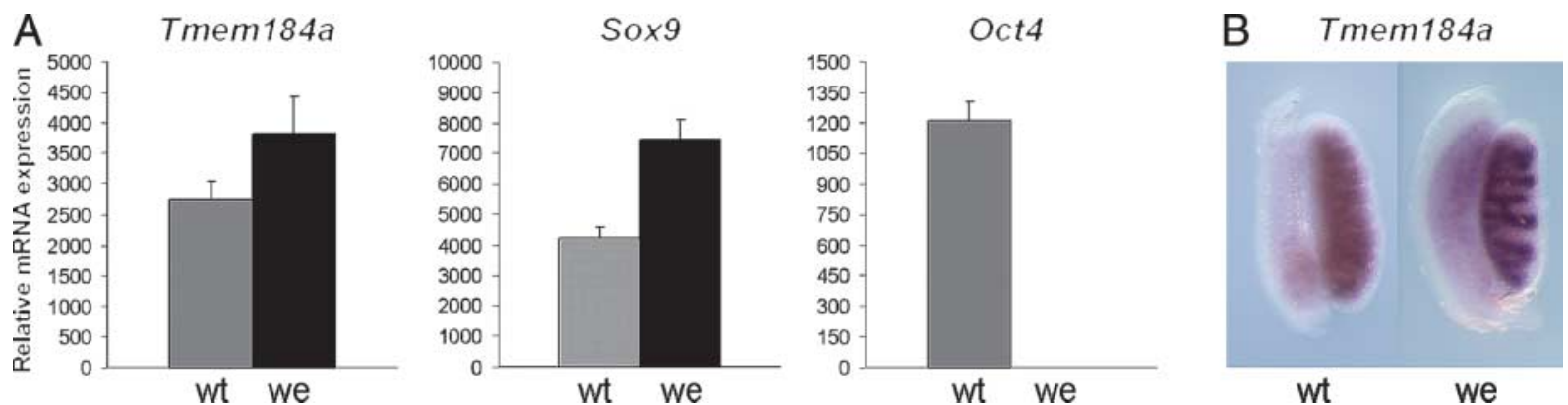

Figure 4 Germ cell-independent Tmem184a expression in 13.5 dpc testes. (A) qRT-PCR analysis of total RNA extracted from $W^{e} / W^{e}$ versus pooled wild-type $(+/+)$ and heterozygous $\left(+/ W^{e}\right)$ littermate gonads using gene-specific primers for Tmem184a, Sox 9 (Sertoli cell marker), and Oct4 (germ cell marker) relative to $18 S$ RNA (mean \pm S.E.M. of three independent experiments). Individual experiments were performed in triplicate on RNA obtained from pooled gonads from 3 to 4 littermates. Tmem184a shows similar expression to Sox 9 and is maintained in germ cell-depleted gonads. In comparison, Oct4 expression was lost in the $W^{e} / W^{e}$ samples. (B) WISH analysis comparing Tmem 184a gene expression in $W^{e} / W^{e}$ and wild-type $(+/+)$ male gonads. Tmem184a-specific staining is seen in both wild-type and littermate $W^{e} / W^{e}$ gonads (wt, wild-type $(+/+)$ and heterozygous $\left(+/ W^{e}\right)$ littermates; we, homozygous $W^{e} / W^{e}$ mutants $)$. 

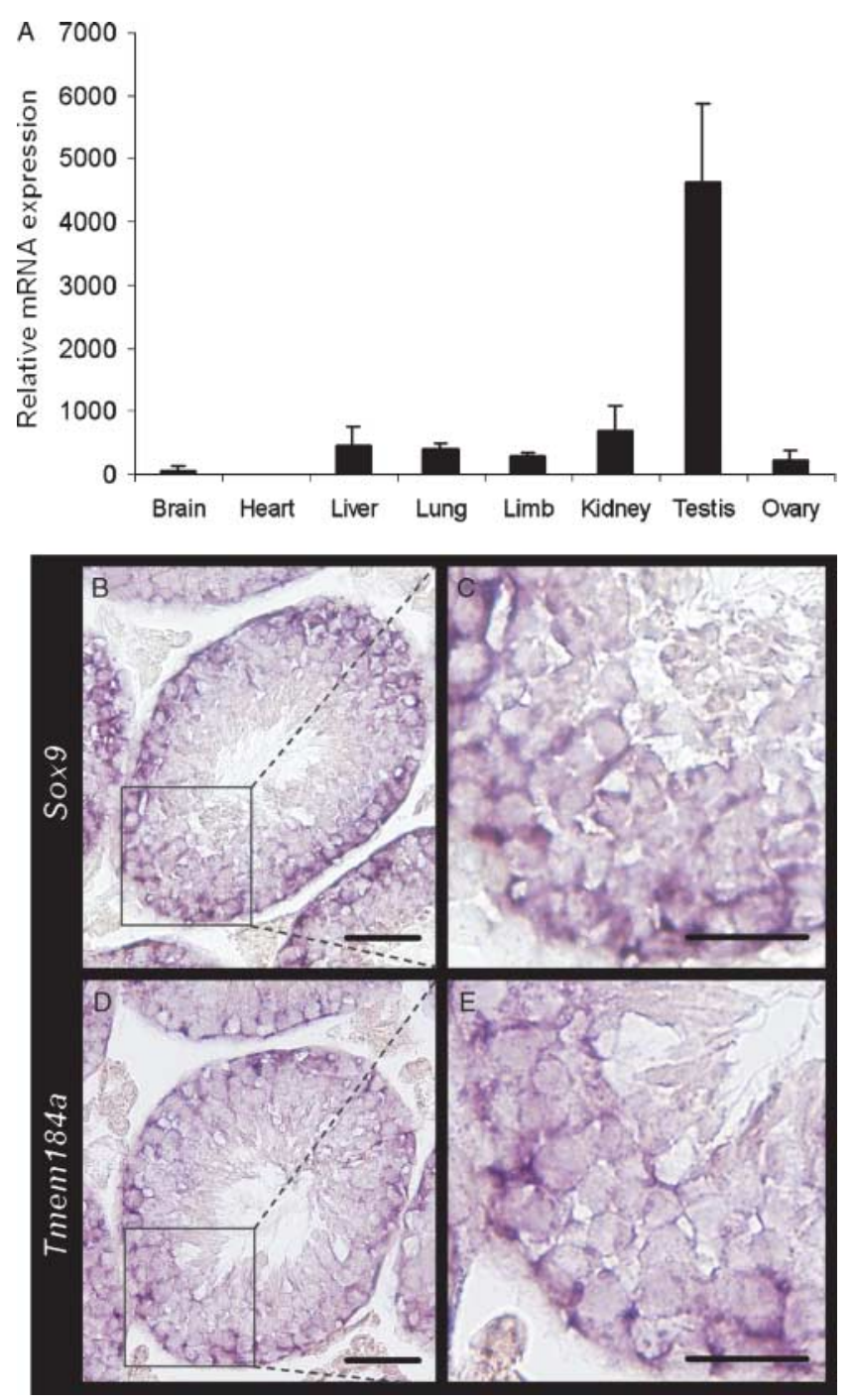

Figure 5 Testis-specific expression of Tmem184a in the adult mouse. (A) qRT-PCR analysis of Tmem184a mRNA expression relative to $18 S$ RNA (mean \pm S.E.M. of three independent experiments, each performed in triplicate) in adult mouse tissues. The three independent biological samples represent two female and one male adult CD1 mouse, with the gonadal tissues represented by three individual ovaries and testes.

Tmem184a shows high expression in testis and only weak expression in ovary, liver, lung, limb, and kidney. No expression was detected in the adult heart. One brain sample showed low levels of expression, but no expression was detected in the other two samples examined. SISH staining using specific probes for Sox9 (B and C) and Tmem 184a (D and E) shows a continued Sertoli cell-specific expression in the adult testis. Boxed areas in $B$ and $D$ indicate regions shown in $C$ and $E$ respectively. Scale bar $=50 \mu \mathrm{m}(B$ and $D) ; 25 \mu \mathrm{m}(C$ and $E)$.

development and demonstrate a specific up-regulation in the Sertoli cells of the testis. Tmem184a expression is activated in XY gonads from $11.5 \mathrm{dpc}$ onwards, $\sim 24 \mathrm{~h}$ after the onset of Sry expression and coincident with the up-regulation of Sox9 (Kent et al. 1996, Morais da Silva et al. 1996). This expression profile observed in early gonadal development strongly suggests a role for Tmem184a in testis differentiation.
The 449 amino acid TMEM184A protein contains seven putative transmembrane helices, strongly suggesting a role in transmembrane signaling pathways acting in or on developing Sertoli cells. It is possible that Tmem184a may mediate signaling between germ cells and Sertoli cells, or between other somatic cells and Sertoli cells, or alternatively within regulatory pathways governing architectural compartmentalization of the testis. In addition, the expression of Tmem184a in the adult testis suggests a continuing role for TMEM184A function. Although detectable in other tissues in both fetal and adult mice, the expression of Tmem184a was significantly higher in testes, strengthening the concept that TMEM184A may elicit specific functions limited to the testis, potentially mediating a male-specific cascade of phosphorylation during Sertoli cell differentiation and/or function. In addition, the restricted expression pattern of Tmem184a makes this gene an excellent target for functional analysis by gene targeting in mice.

Due to the observed tissue-specific expression of Tmem184a and its up-regulation from $11.5 \mathrm{dpc}$, we hypothesize a close transcriptional regulation with the testis-determining factor SRY, either directly or indirectly. After the onset of Sry expression in the pre-Sertoli cell lineage around $10.5 \mathrm{dpc}$, the testis enters an active phase of proliferation and differentiation, which dictates both inter- and intracellular signaling pathways, almost certainly involving kinase pathways and phosphorylation cascades. However, as Tmem184a expression persists into adulthood, we hypothesize that TMEM184A function is distinct from sex determination, but is integral to testis differentiation. Further studies will focus on determining protein structure and sub-cellular localization in order to better understand the likely cellular functions of TMEM184A protein. It will be especially beneficial to elucidate whether TMEM184A is a cellular transduction molecule or kinase receptor, ultimately allowing for extensive in vitro and ex vivo studies after the characterization of effector molecules.

\section{Acknowledgements}

PK is a Professorial Research Fellow of the Australian Research Council (ARC). We acknowledge grant support from the ARC and the National Health and Medical Research Council of Australia. The authors declare that there is no conflict of interest that would prejudice the impartiality of this scientific work.

\section{References}

Albrecht KH \& Eicher EM 2001 Evidence that Sry is expressed in preSertoli cells and Sertoli and granulosa cells have a common precursor. Developmental Biology 240 92-107.

Barrionuevo F, Bagheri-Fam S, Klattig J, Kist R, Taketo MM, Englert C \& Scherer G 2006 Homozygous inactivation of Sox 9 causes complete XY sex reversal in mice. Biology of Reproduction 74 195-201. 
Beverdam A \& Koopman P 2006 Expression profiling of purified mouse gonadal somatic cells during the critical time window of sex determination reveals novel candidate genes for human sexual dysgenesis syndromes. Human Molecular Genetics 15 417-431.

Brennan J \& Capel B 2004 One tissue, two fates: molecular genetic events that underlie testis versus ovary development. Nature Reviews. Genetics 5 509-521.

Buehr M, McLaren A, Bartley A \& Darling S 1993 Proliferation and migration of primordial germ cells in We/We mouse embryos. Developmental Dynamics 198 182-189.

Burgoyne PS, Buehr M, Koopman P, Rossant J \& McLaren A 1988 Cellautonomous action of the testis-determining gene: Sertoli cells are exclusively XY in XX-XY chimaeric mouse testes. Development 102 443-450.

Chaboissier M-C, Kobayashi A, Vidal VPI, Lutzkendorf S, van de Kant HJG, Wegner M, De Rooij DG, Behringer RR \& Schedl A 2004 Functional analysis of Sox8 and Sox9 during sex determination in the mouse. Development 131 1891-1901.

Hargrave M, Bowles J \& Koopman P 2006 In situ hybridization of whole-mount embryos. Methods in Molecular Biology $\mathbf{3 2 6}$ 103-113.

Karl J \& Capel B 1998 Sertoli cells of the mouse testis originate from the coelomic epithelium. Developmental Biology 203 323-333.

Kent J, Wheatley SC, Andrews JE, Sinclair AH \& Koopman P 1996 A male-specific role for SOX9 in vertebrate sex determination. Development 122 2813-2822.

Koopman P, Munsterberg A, Capel B, Vivian N \& Lovell-Badge R 1990 Expression of a candidate sex-determining gene during mouse testis differentiation. Nature 348 450-452.

Martineau J, Nordquist K, Tilmann C, Lovell-Badge R \& Capel B 1997 Male specific cell migration into the developing gonad. Current Biology 7 958-968.

Morais da Silva S, Hacker A, Harley V, Goodfellow P, Swain A \& LovellBadge R 1996 Sox9 expression during gonadal development implies a conserved role for the gene in testis differentiation in mammals and birds. Nature Genetics 14 62-68.

Münsterberg A \& Lovell-Badge R 1991 Expression of the mouse antiMüllerian hormone gene suggests a role in both male and female sexual differentiation. Development 113 613-624.
Nef S, Schaad O, Stallings NR, Cederroth CR, Pitetti J-L, Schaer G, Malki S, Dubois-Dauphin M, Boizet-Bonhoure B, Descombes P et al. 2005 Gene expression during sex determination reveals a robust female genetic program at the onset of ovarian development. Developmental Biology 287 361-377.

Schepers G, Wilson M, Wilhelm D \& Koopman P 2003 SOX8 is expressed during testis differentiation in mice and synergizes with SF1 to activate the Amh promoter in vivo. Journal of Biological Chemistry 278 28101-28108.

Sekido R, Bar I, Narvaez V, Penny G \& Lovell-Badge R 2004 SOX9 is up-regulated by the transient expression of SRY specifically in Sertoli cell precursors. Developmental Biology 274 271-279.

Strausberg RL, Feingold EA, Grouse LH, Derge JG, Klausner RD, Collins FS, Wagner L, Shenmen CM, Schuler GD, Altschul RD et al. 2002 Generation and initial analysis of more than 15000 full-length human and mouse cDNA sequences. PNAS 99 16899-16903.

Val P, Jeays-Ward K \& Swain A 2006 Identification of a novel population of adrenal-like cells in the mammalian testis. Developmental Biology 299 250-256.

Vidal VPI, Chaboissier M-C, de Rooij DG \& Schedl A 2001 Sox9 induces testis development in $\mathrm{XX}$ transgenic mice. Nature Genetics 28 216-217.

Wilhelm D \& Koopman P 2006 The makings of maleness: towards an integrated view of male sexual development. Nature Reviews. Genetics 7 620-631.

Wright E, Hargrave MR, Christiansen J, Cooper L, Kun J, Evans T, Gangadharan U, Greenfield A \& Koopman P 1995 The Sry-related gene $50 x 9$ is expressed during chondrogenesis in mouse embryos. Nature Genetics 9 15-20.

Received 19 December 2006

First decision 26 January 2007

Accepted 13 February 2007 